\title{
3. All Other Loves Excelling: Mary Kidder, Wakamatsu Shizuko and Modern Marriage in Meiji Japan
}

\author{
Rebecca Copeland \\ Washington University in St. Louis (USA) ${ }^{1}$
}

\section{Introduction}

The adage, "Do as I say, not as I do," might well have been on the lips of American missionary women in Japan at the turn of the twentieth century. As Jane Hunter, a historian whose work has focused on missionary women in China, observes, "The message of Christian domesticity preached by missionary women [in China] was less transformative than the force of their own example." ${ }^{2}$ Trained "in submission, service, and love, all objects of the mission cause," American women were thought to be inherently suited to serving Christian goals. But more often than not, as these women crossed into unfamiliar territory, they also found themselves at odds with the very values and behaviours they were intent on projecting. Karen Seat notes in her study of American women missionaries in Japan, "Conservative American ideologies of womanhood, in fact, were powerfully undermined by the very women who were charged to promote them - namely, white Protestant missionary women. While nineteenthcentury missionaries were often the purveyors of what amounted to sexist and racist ideologies compatible with the age of imperialism, the mission movement was much more complicated and much less predictable than any such onedimensional depiction." ${ }^{4}$ Committed to promoting Victorian notions of modesty and encouraging the establishment of Christian homes, these missionaries frequently discovered that their efforts generated surprising outcomes. This chapter will focus on one such case in late nineteenth-century Japan by

\footnotetext{
1 I visited the following archives and repositories: Ferris University Library Archives (FULA), Yokohama, Japan and the library at the International Christian University (ICU), Mitaka, Japan. At ICU, I accessed the Jogaku zasshi a set of journals. All other research was conducted at my home institution, Washington University in St. Louis, Missouri, USA.

2 Jane Hunter, "The home and the world: the missionary message of U.S. domesticity," in Women's Work for Women: Missionaries and Social Change in Asia, ed. Leslie A. Flemming, Boulder, San Francisco and London: Westview Press, 1989, pp. 159-66, p. 164.

3 Barbara Welter, "She hath done what she could: Protestant women's missionary careers in nineteenthcentury America," American Quarterly, Special Issue: Women and Religion 30(5) (Winter 1978): 624-38, p. 626. 4 Karen Seat, "Providence Has Freed Our Hands" Women's Missions and the American Encounter with Japan, Syracuse, NY: Syracuse University Press, 2008, p. 4.
} 
exploring the relationship between Miss Mary Kidder, a missionary with the Reformed Church in America who was sent to Japan in 1869, and her student Wakamatsu Shizuko, an orphan who would eventually become a prominent woman writer, journalist, educator and translator.

\section{Mary Kidder and the romance of mission work}

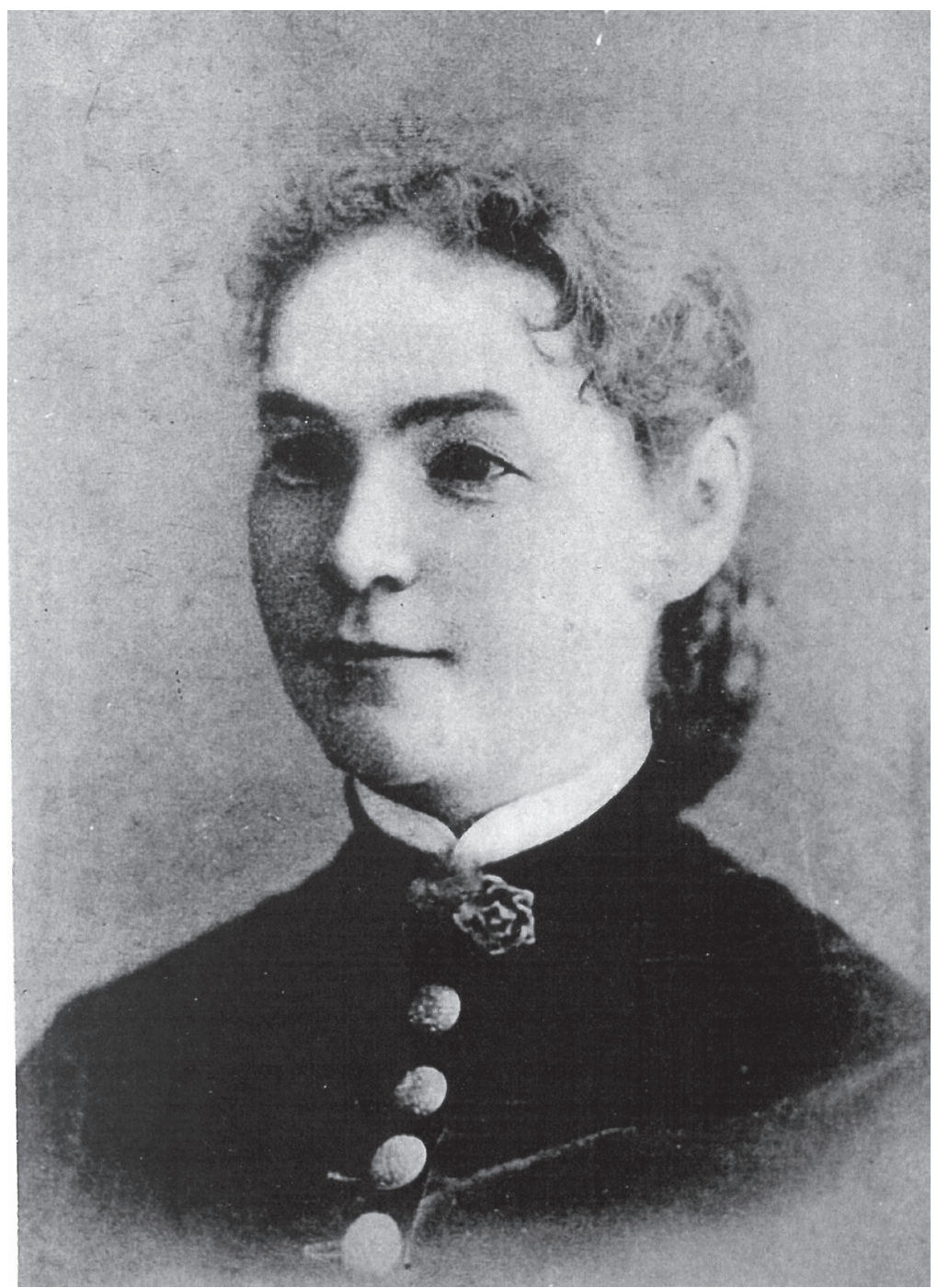

Figure 7. A youthful Mary E. Kidder (1834-1910)

Source: Ferris University Library Archives. 
A graduate of Monson Academy in Massachusetts and a teacher at various private schools throughout the Northeast, Mary E. Kidder (1834-1910), was eager to do more in service to society (see Figure 7). She worked for a time in Brooklyn, New York, catering to the dispossessed. She thought of applying to the missions that were then evangelising among Native Americans. But when she met Dr Samuel Robbins Brown (1810-1880), ${ }^{5}$ a missionary to Japan with the Reformed Church of America, she was convinced that she should be sent to Japan. Apparently, Mary had wished to depart for the mission fields even earlier, but personal hindrances always interfered. Once, when she was "but a school girl," her father had intervened. Another time there were "more paramount claims" on her life. ${ }^{6}$ And yet a third time, she had to deny foreign mission service because she had been saddled with family responsibilities - nursing a sickly sister after their mother's death. But in 1869, a healthy and independent thirty-five-year old and with "all hindrance of a personal character now being removed,"7 Mary was ready to accompany the Browns on their return to Japan.

When she presented herself to the Board of Foreign Missions of the Reformed Church in America, she spoke of her excitement over the "romance" of the adventure but hastily added that she was led by Providence in her request to be sent to Japan. Indeed, she was to announce in a letter home to family just before her departure that though friends and acquaintances thought to dissuade her from leaving, "nothing but a direct interposition by Providence or some insurmountable obstacle will prevent me from going." ${ }^{8}$ Dr S.R. Brown vouched for her suitability, arguing that she could be instrumental-once she had acquired the language - of administering to Japanese womanhood, "a work that must be done before that nation can be [welcomed to its] place among Christian nations and which ought to be begun now." ${ }^{\prime 9}$ And so, the Missionary

5 S.R. Brown had studied at Amherst, Yale and Union Seminary in New York. In 1838 he set out for missionary work in Macao with his bride, Elizabeth Bartlett. Here he met Dr James Curtis Hepburn, a physician and Presbyterian missionary who would soon be influential in Japan. Brown returned to the United States in 1847 to allow Elizabeth, who had had three children, to recover from a lingering illness. While in the United States, Brown served as the headmaster for the newly opened Roma Academy in New York. Additionally, he became the pastor of a Dutch Reformed church in Lake Oswego and a teacher at Springside Boarding School for Boys in Auburn, New York. It was at this institution that Mary Kidder became acquainted with him.

6 Mary Kidder, Brooklyn, New York, to Dr J.M. Ferris, New York, 3 May 1869, p. 5. Mary Kidder Miller's Letters to Dr J.M. Ferris (1869-1878) are archived in the Ferris University Library Archives (FULA), Yokohama, Japan.

7 Mary Kidder, Brooklyn, New York, to Dr J.M. Ferris, New York, 1 March 1869, p. 4.

8 From a digest of Mary Kidder's letters home, as compiled by her great-niece, Elizabeth Kidder Morton, and presented by her to Ferris Women's School on 14 June 1972, (FULA). This letter is dated 28 March 1869, Brooklyn, New York. It was the last letter sent to her family in Wardsboro, Vermont before she departed for Japan.

9 Dr S.R. Brown's recommendation of Mary Kidder, Brooklyn, New York, to Dr J.M. Ferris, New York, 28 February 1869 (FULA). As collected in her letters to Dr J.M. Ferris, p. 2. In places where the handwritten letters were illegible, the copyist left blanks. These are represented by [brackets] enclosing my own guess at what might be missing. 
Board of the Reformed Church in America dispatched Mary to Japan in the summer of 1869, making her the first single North American missionary woman to enter the nation.

Mission boards understood that the most important means for rooting Christianity in native soil was through the establishment of Christian homes. And women were the key. Or, as one missionary is noted to have claimed: "You cannot evangelize a country until you convert the women. ${ }^{10}$ Given the sensitive nature of evangelising to native women, female missionaries were essential. For one thing, it was more natural for women to interact with other women, particularly in countries such as Japan, where women were denied contact with men outside the family, particularly foreign men. For another, the missionary woman could better demonstrate the "Christian" way of raising children, which was believed to be more loving, more involved and healthier for both mother and child. ${ }^{11}$ But married women were often too preoccupied with this very task, and sadly at times too haggard from successive childbirth in their adopted lands, to engage their native counterparts. Mission boards, often at the urging of affiliate women's boards, began to send single women to the foreign fields, in the hope that they might best accommodate the needs of the native woman. These single female missionaries, given the kind of intimacy that they were able to establish with the women in their midst, were profoundly influential, though their success was often accompanied by unexpected tensions and contradictions. As Seat observes, "Protestant women's missions opened up a space of legitimacy for American women who actually did not fulfill domestic roles, as they were able to justify leaving their own domestic sphere to build a vast mission movement focused on employing unmarried missionary women." ${ }^{12}$ Moreover, these mission women were often involved in enterprises, such as schools and charities, that depended on the work of native women, thus drawing them further and further out into the public sphere and away from their domestic duties.

Mary spent most of her first year in Japan in the remote region of Niigata. By sheer diligence and determination she managed to teach herself Japanese, using “Hepburn's Dictionary, first edition-Brown's Grammar, and a very small pamphlet of Aston's - I do not remember the title; and the help of a young girl who came to me to learn English." ${ }^{13}$ Much to Mary's delight - and to the Browns' keen disappointment - a salary dispute between the Japanese government and

10 As cited in Seat, "Providence Has Freed Our Hands," p.57.

11 Marjorie King, "Exporting femininity, not feminism: nineteenth-century U.S. missionary women's efforts to emancipate Chinese women," in Women's Work for Women: Missionaries and Social Change in Asia, ed. Leslie A. Flemming, Boulder, San Francisco and London: Westview Press, 1989, pp. 117-35.

12 Seat, "Providence Has Freed Our Hands," p.57.

13 Mary Kidder Miller, “The Christian movement in Japan,” Japan Evangelist (August 1909): 126-27, p. 126. 
Dr Brown forced the party to leave Niigata and return to Yokohama. ${ }^{14}$ By July 1870 they were back in the thriving metropolis, which Mary described as being tantamount to a return to New York City.

In Yokohama, Mary could set about doing the job that she felt she had been called to do: teach women. Because single foreign women in Japan were required to have some sort of employment, ${ }^{15}$ Mary officially became a teacher of English, an occupation that freed her somewhat from her obligations to the Browns. But it did not accord with what she felt was her "mission." Mary was intent on establishing a school for women. As Hyaeweol Choi notes, "Missionaries put a priority on educating girls and women as the fastest way to introduce the Bible and Christian teachings." 16 Of course, Japan at the time still restricted Christianity, and missionaries were not allowed to proselytise directly. But Mary and others of her generation held firmly to the idea "that national progress was associated with the status of women in society." 17 Mary's early letters to Dr J.M. Ferris, General Secretary of the Board of Foreign Missions of the Reformed Church, teem with an enthusiastic desire to strike out on her own and get the job done. She was full of ideas for establishing schools. Her main requirements were firstly that she should teach only women; and secondly that she should be able to communicate directly with her students without the hindrances of the foreign community. Her dreams, however, would be long in the making.

From October 1870, she was asked to assist the Presbyterian missionary Mrs. Clara Hepburn (1818-1906), wife of Dr James Curtis Hepburn (1815-1911). Best known today for his work in compiling the first Japanese-English dictionary - the one Mary used to learn Japanese - and for the system of Romanisation that bears his name (and is still considered standard today), Dr Hepburn was also extremely active in translating the Bible into Japanese. From 1859 he and his wife had run a compound in Yokohama where he practised medicine, taught a variety of subjects from English to theology, and, once the practice of Christianity was allowed in 1873, openly conducted worship services. His wife had been teaching an English class for boys and girls on the compound since 1867. Just prior to Mary's arrival, however, she had been saddled with the

\footnotetext{
14 According to Miller, "The Christian movement in Japan," p. 126, the government claimed the dispute was over salary. But Mary suggested that the real dispute concerned Dr Brown's insistence on teaching his students about the Bible - a practice that was then disallowed.

15 Elizabeth Kidder Morton's editorial note on the year 1870 of Mary Kidder Miller's Letters home, 1869-1870.

16 Hyaeweol Choi, Gender and Mission Encounters in Korea: New Women, Old Ways, Berkeley: University of California Press, 2009, p. 19.

17 Rui Kohiyama, “'No nation can rise higher than its women.' The women's ecumenical missionary movement and Tokyo Woman's Christian College," in Competing Kingdoms: Women, Mission, Nation, and the American Protestant Empire, 1812-1960, ed. Barbara Reeves-Ellington, Kathryn Kish Sklar and Connie A. Shemo, Durham, NC: Duke University Press, 2010, pp. 218-39, p. 220.
} 
care of an infant whose missionary parents, Mr and Mrs. Edward Cornes, had died in an explosion aboard a ship in Tokyo Bay. Mary, therefore, assumed Mrs. Hepburn's work with the English class.

Clearly grateful for the opportunity, teaching English had nevertheless not been the life's work that Mary had had in mind. As she had written to Ferris while still in Niigata, "If it seems best I hope when I have a sufficient knowledge of Japanese that instead of teaching English that I may give my whole attention to religious instruction in their own language."18 The following September, after the Hepburns had left for Shanghai to attend to the publication of his dictionary and the translations of the Gospel of Mark, Mary limited the class to girls. And thus the inauguration of "Miss Kidder's School for Girls," known as the first school of higher learning for women in Japan. In October 1871 she had twelve girls:

Seven of them are from fourteen to seventeen \& the remaining five are eight to ten, since very small they seem about like the children in America at five or six. All these girls are bright and very quick and no one of them has been more than three mornings in learning her alphabets, large and small letters \& one learned the whole the first day.

I have taught them several hymns \& they sing "Jesus loves me" beautifully.... The very smallest one who is but a mite of a child sings very sweetly and with a clear voice that can be heard distinctly above the others and it would do your heart good to hear their dear little voices so sweetly singing these precious hymns \& to feel that the day may be near when their hearts will respond. It seems to me that great things are in store for us concerning this people. ${ }^{19}$

Although she would give the names of her students in other letters, here she does not, leaving biographers to puzzle as to whether or not this tiny mite of a child was the seven-year-old Wakamatsu Shizuko, the other focus of this present study. ${ }^{20}$

\section{Wakamatsu Shizuko - an orphaned childhood}

Names, like lives and family bonds, were ephemeral during the turbulent years surrounding the Meiji Restoration of 1868. When Shizuko was born in Aizu-

18 Mary Kidder, Niigata, Japan, to Dr J.M. Ferris, New York, 2 February 1870, pp. 14-15.

19 Mary Kidder, Yokohama, to Dr J.M. Ferris, New York, 21 October 1871, pp. 19-20.

20 Honda Hayao, "Wakamatsu Shizuko no uketa kyōiku no kurisutokyō to shūhen- toku ni misu kidā ni tsuite" [The educational background of Shizuko Wakamatsu—The association with Miss Kidder], Fukushima joshi tanki daigaku kenkyū kiyō 10 (1988): 1-18, p. 11. 
Wakamatsu, she was given the name "Kashi," in honour of the fact that she had been born on the "first calendar sign" (ki'noene) in the sixty-cycle zodiac. She was the first child, and the name augured a bright future. With its additional meaning of "armour," the name was fitting for a Samurai daughter. Her father had been adopted into the Matsukawa household, having originally been a member of the Furukawa family. To complicate matters, he changed his name because of his activities in the Kyoto region as a spy for the Aizu clan. Hereafter, he and his immediate family were registered under the name Shimada. Shizuko, therefore, spent the first five years of her life as Shimada Kashi. Her name would go through several other permutations, however, before she emerged as Wakamatsu Shizuko - a name she selected for herself (see Figure 8). ${ }^{21}$

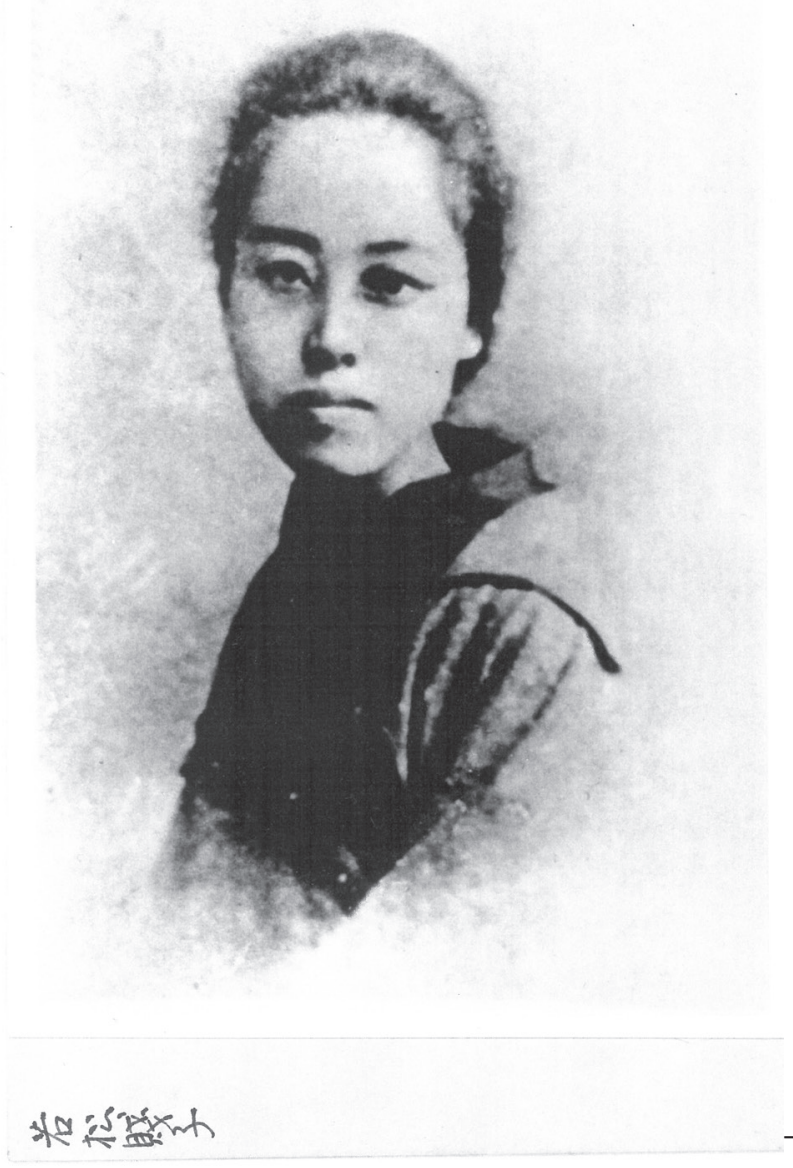

Figure 8. Wakamatsu Shizuko as a young girl (1864-1896)

Source: Ferris University Library Archives.

21 She began using the penname in 1886: Wakamatsu from the place of her birth, and Shizu meant "God's servant." 
Following the defeat of the Aizu clan in November 1868, Shizuko's father escaped to Hokkaidō. Eventually he was captured and imprisoned, but none of this information reached Shizuko's family, who had been sent with other members of the Aizu clan to a barren strip of land in northern Aomori. Shizuko's mother died shortly thereafter, and Shizuko, now assumed to be an orphan, was adopted out to a family in Yokohama. Overnight she became Ōkawa Kashi.

Shizuko's adoptive father was a silk thread merchant with the Yamashiroya in Yokohama. His wife was a former prostitute. Shizuko joined the couple in the summer of 1870 when she was six. Bereft of her father and still grieving for her mother, Shizuko felt disoriented, confused and completely abandoned. To compound her discomfort, she fell ill. Perhaps in an effort to give his wife some respite from the sulky child, or perhaps in an effort to join the newly "civilised," Mr Ōkawa decided to enroll Shizuko in Miss Kidder's School. And so off she went every morning to the Hepburn compound.

\section{From Noge Hill to the Yamate Bluffs}

Miss Kidder had been conducting her "school" in the dispensary on the Hepburn compound - a small second-floor room. When she had only needed to accommodate a few little girls, the space was tolerable. But by January 1872 she had nineteen; twenty-two in February. To compound Mary's problem, the Hepburns were scheduled to return from Shanghai in the fall of 1872 and begin using the dispensary again, forcing Mary to seek new quarters for her burgeoning school. Help was soon to come from the governor of Yokohama, Ōe Taku, whose young wife happened to be one of Mary's students. Governor Ōe secured a house for Mary on Noge Hill in "a part of the native town where all the highest government officers of this place reside." ${ }^{22}$ Most of the pupils, Mary noted in her letter to J.M. Ferris, were from the Noge Hill area and were delighted with the change and with their pretty new school house. Shizuko, however, was not. The Ōkawa residence was now too far, and she had no choice but to withdraw until Miss Kidder opened a boarding school in 1875.

Miss Kidder was now Mrs. Miller, having married E. Rothesay Miller, a Presbyterian missionary, in 1873. I will return to a discussion of their marriage below. But first I will continue describing Mary Kidder's struggle to create and maintain her "school for girls." In Mary's letters to J.M. Ferris, she returns again and again to her request for money to open a school of her own, a school where she can exercise the kind of influence over "her girls" that she thinks is necessary; a school where they can all live together in Christian love. To have 
this school Mary needed land from the Japanese government, money from the mission, and assurances from both that she would have the wherewithal to maintain what she had created. From the government she wanted the promise of a rent-free lease. From the mission she wanted the promise of an assistant, preferably one who could play the cabinet organ or if not, someone middle age "who can take care of the house." ${ }^{23}$ Her demands seemed impossible. But Mary, as is clear from her correspondence, was not easily deterred. She was tenacious and astute in her negotiations with both the Japanese government and the mission. In November of 1874, after two years of discussion, she was able to secure a piece of land that was "beautifully situated, can be seen from this bay and the whole town, but is very retired, and is by far the best lot for a girls' school that there is in Yokohama." 24

Having finally secured the land, Mary set about seeing to the building of her school. The total cost of the construction was $\$ 5,500$. The mission would guarantee only $\$ 5,000$. Mary's husband, E. Rothesay Miller, contributed the remaining $\$ 500$ from his personal funds. ${ }^{25} \mathrm{He}$ also designed the structure, which consisted of a large classroom on the first floor in addition to a library, recitation room, study, scholars' dining room, kitchen and a large work room. On the second floor there were three bedrooms 18 x 18 feet (approximately $5.5 \times 5.5$ metres); and thirteen $12 \times 6$ feet (approximately $3.6 \times 1.8$ metres), in addition to bathrooms, closets and a large hall. ${ }^{26}$ The rooms that the girls would use were floored with tatami so that the girls could sleep on futon, in accordance with Japanese customs,

as we do not think it wise to educate them so that they cannot live in their own homes and there seems to be some danger of that. I do not suppose there is one single Japanese family from the Emperor down who lives commonly in a foreign way. There are but few who can afford it even if they wish it, so for the present, I propose that our pupils shall have enough of Japanese surroundings to remind them of home. ${ }^{27}$

Other Western educators in Japan believed the West reflected the height of civilisation and moreover that "the US most closely reflected God's kingdom on earth, and that their country should therefore serve as a model for all the world." 28 These educators wished the Japanese to adopt more fully a Westernised lifestyle. And for a brief period, as Japan rapidly modernised in an effort to overturn the Unequal Treaties, it seemed the nation was on the path to just such a

\footnotetext{
Ibid., 7 March 1874, p. 60.

Ibid., 8 November 1874 , p. 65.

Ibid., 8 January 1875, pp. 70-71.

From a digest of Mary Kidder's letters home, 25 April 1876, Yokohama.

Mary Kidder, Yokohama, to Dr J.M. Ferris, New York, 3 December 1874, pp. 67-68.

Seat, "Providence Has Freed Our Hands," p. 48.
} 
transition. But by the late 1880s authorities began to criticise Western educators for trying to make "European or American women out of our daughters, and their educational efforts tended to produce undiscriminating Westernization, which our country does not want." ${ }^{29}$ Mary, as the above quotation makes clear, took a more measured approach. Her students wore Japanese kimono, although she did require them to wear a cotton chemise underneath, presumably for hygienic reasons as they could wash these once a week - something that could not be done easily with kimono. Their food was typically Japanese. On special occasions they had Western meals and Mary insisted that each girl learn to use tableware properly. In their lessons as well Mary's focus was not exclusively on English. By 1875 she had quite mastered her own lessons in Japanese and was teaching daily in the language, as had been her goal. By now she had on her staff an American assistant, sent by the mission board (but apparently not the organplaying middle-aged woman she had desired), and several Japanese teachers. The faculty offered the girls an assortment of subjects: arithmetic, geography, first lessons in philosophy, botany, English, composition. ${ }^{30}$ She also allowed room in the curriculum for Chinese and Japanese studies.

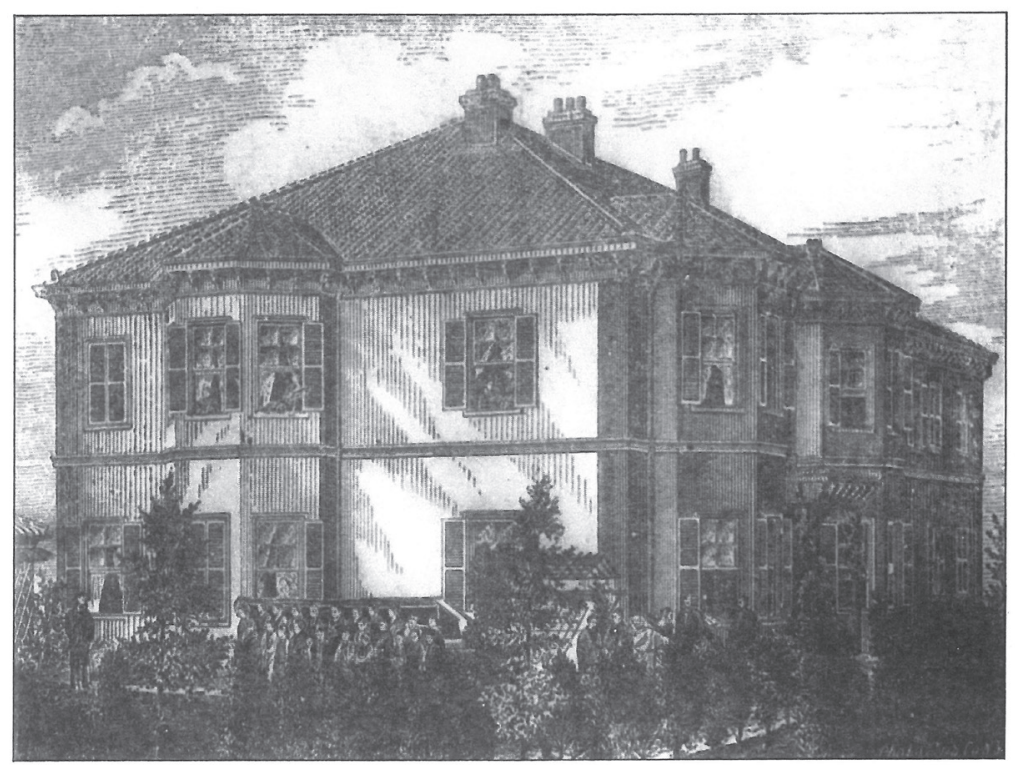

明治 8 年 6 月 1 日 $7 ェ$ リ和英女学校落成校舎

Figure 9. Ferris Seminary

Source: Ferris University Library Archives.

29 Naruse Jinzō (1859-1919), founder of Japan Women's College, as cited in Ann Harrington, “Women and higher education in the Japanese empire (1885-1945)," Journal of Asian History 21 (1987): 169-86, p. 173.

30 From a digest of Mary Kidder's letters home, 4 June 1873, Yokohama. See also Mary Kidder, Yokohama, to Dr J.M. Ferris, New York, 28 December 1875, pp. 75-79. 
Surely the proof of a school's success is in its students. Ferris Seminary-for this is the name by which the school was known after the new facilities were opened in June 1, 1875-produced numerous graduates over the years, some notable (see Figure 9). ${ }^{31}$ But none as distinguished as its first, Wakamatsu Shizuko. ${ }^{32}$

\section{An exception to Darwin's Law}

Wakamatsu Shizuko would become known as Japan's most pre-eminent female translator of English to Japanese. Although she translated a variety of English "classics," such as Charles Dickens and Alfred Lord Tennyson, it is for her translation of Frances Hodgson Burnett's Little Lord Fauntleroy that she is best known. Shizuko's unique translation style helped chart the way for a modern written idiom in Japanese letters. Additionally, she was influential in establishing space in the literary arena for both the woman writer and the child reader (see Figure 10). Her many accomplishments are due to her own talent and tenacity but also owe no small measure to the training that she received from Mary Kidder. Shizuko's comfortable fluency in English, her appreciation of a narrative geared toward the "common reader," her sympathy for children, and her determination to raise the standards of Japanese literature were clearly influenced by Mary's own goals and aspirations. ${ }^{33}$

When Shizuko returned to Mary's school in 1875, she had been tacitly severed from the Ōkawas. It was understood that Ferris Seminary would henceforth be her home. In an early letter to J.M. Ferris Mary described a few of her students by name. Of Shizuko she notes:

Behind little Ko and wearing a very distinct velvet collar is Kashi [Shizuko]. She is from Yedo, speaks English well and wrote the composition about tea. I sometimes think she is a Christian. She understands much of the Bible history - She was my pupil long ago and then when her parents went to Yedo to live she went with them and returned to us when we opened the boarding school. ${ }^{34}$

\footnotetext{
31 The school takes its name from Isaac Ferris, a leader in the Reformed Church and the father of J.M. Ferris who was then Secretary of the Board of Foreign Missions of the Reformed Church.

32 Another Ferris student of note was Sasaki Toyosu (1853-1901) who became active in both the temperance and the anti-prostitution movements.

33 For more on Wakamatsu Shizuko and her contributions to Japanese literature, see Rebecca Copeland, Lost Leaves: Women Writers of Meiji Japan, Honolulu: University of Hawai'i Press, 2000, pp. 99-158.

34 Mary Kidder, Yokohama, to Dr J.M. Ferris, New York, 28 December 1875, pp. 75-79.
} 


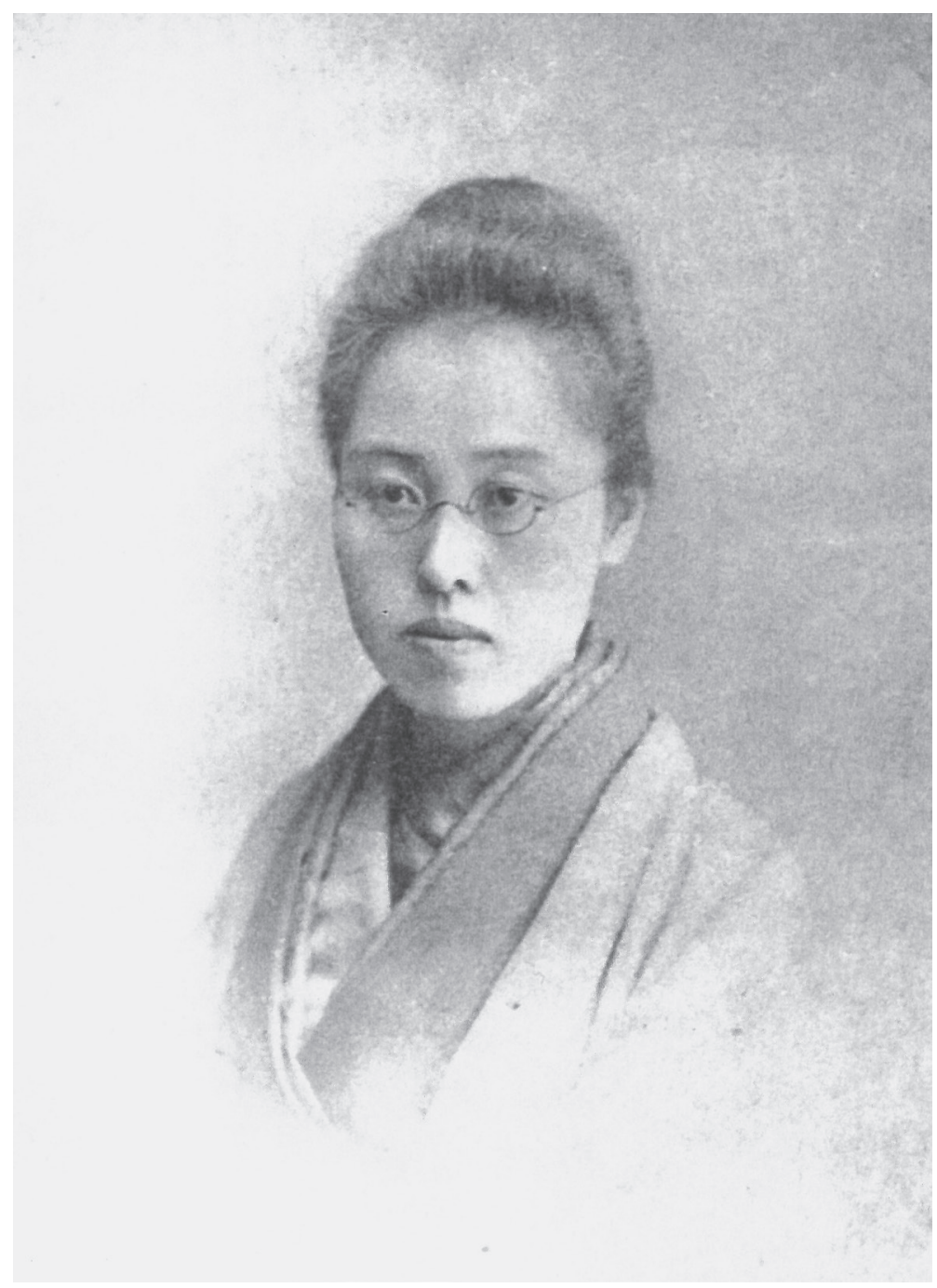

Figure 10. Wakamatsu Shizuko, translator, author, educator

Source: Ferris University Library Archives.

It is clear that Mary doted on Shizuko, and on the other boarders - most of whom rarely had occasion to return home during the school year. Mary and her husband frequently had the girls into their own home, not far from the seminary, where they treated them to Western meals. On Christmas Day they had special celebrations - providing each little girl with dolls and a stocking full of presents. Or as Mr Miller describes the event in a letter to a Sunday School class back in the United States: 
Two years ago the girls in our school had their stockings hung up on a sofa in the schoolroom and getting up early in the morning enjoyed opening them and finding their presents just as you do at home. I do not mean they have their own stockings hung up because they only wear funny little socks with a place to put the big toe in like a mitten. Mrs. Miller lent them her long stockings. ${ }^{35}$

Shizuko was baptised in 1877 at the age of thirteen. The Reverend Rothesay Miller performed the ceremony at the Yokohama Kaigan Church. Now a Christian, and at last part of a family, Shizuko worked tirelessly for Ferris Seminary and for her new faith. Mary proudly reported to the Woman's Board in 1878 that Shizuko and a classmate had received permission to teach on Sunday in a private Japanese school, thus establishing their own little Sunday School. Since Shizuko admittedly looked to Mary Kidder as her surrogate mother, confiding in her "what she does to no one else," ${ }^{36}$ it devastated her when Mary decided to return to the United States on furlough in 1879. Mary did not return until 1881. Mary's role at the school was temporarily filled by her assistant Miss Emma Whitbeck, another single missionary with the Reformed Church. In later correspondence with J.M. Ferris, Mary would divulge her great dissatisfaction with Miss Whitbeck. It seems that the latter was a proud woman, hardly the middle-aged housekeeper that Mary had requested! Apparently, her interaction with the girls in the school had been extremely perfunctory: "There was also no sympathy with the pupils. Miss W. taught them during school hours very well but seldom saw or spoke to any of them beside. No one knew or seemed to care anything about their personal joys or sorrows. I think this has been one of the greatest obstacles to the prosperity of the school." ${ }^{37}$ Indeed, by the time Mary returned the student body had dwindled to a mere eighteen, having seen a healthy average of thirty-seven students in 1878 .

Upon her return to Japan, Mary and her husband resided in the Tsukiji area of Tokyo where they were engaged in a new project unrelated to the school. Shizuko visited Mary regularly to help her with her work-she was then beginning to publish a Japanese-language gazette known as Yorokobi no Otozure (Glad Tidings) aimed at women and children. Shortly she would begin issuing a monthly just for children, which she called Chiisaki Otozure (Little Tidings). Over the summer of 1882, Shizuko stayed with Mary and helped her with these publications. During their days together, she would confide in Mary, describing her discouragement and disappointment in the school. Several of Shizuko's classmates had left the school to marry and most were not happy in their marriages. Shizuko saw very little future for herself, imagining that if

35 Ibid., 10 January 1879, pp. 79-84.

36 Mary Kidder, Tsukiji, Tokyo, to Dr J.M. Ferris, New York, 19 January 1882, p. 89.

37 Ibid., p. 86. 
she too must end up in an unhappy marriage, what had been the point of her education. She considered withdrawing from the school. But Mary did what she could to restore Shizuko's determination. She wrote, "Although I never allowed her to know how I felt about it, and it required all my persuasion almost my authority to make her return to it. She is a noble girl, duty alone led her back to school to do what good she could." 38

Apparently Mary's advice proved sound. Miss Whitbeck was shortly to resign from her post and was replaced by Mr and Mrs. Eugene S. Booth. According to Mary "it seems like the beginning of a bright day for the school." ${ }^{39} \mathrm{Mr}$ Booth proved to be a very capable administrator and teacher. Under his care, Ferris Seminary produced its first graduating class. It was a class of one: Wakamatsu Shizuko. Shizuko would say of her accomplishment several years later: "The school conferred a certificate on the sole survivor of a class whose fate must always be an argument against Darwin's favorite theory." ${ }^{40}$ Despite the smallness of the graduating class, Mr Booth spared no formality. He had a proper ceremony, inviting an assemblage of distinguished missionaries and Japanese, and he required that Shizuko give the English speech that she had prepared and rehearsed for two days. It is clear that Booth, like his predecessor, was exceedingly fond of Shizuko. He would say of her that she had not only mastered the idiom of the English language, but she possessed the

exceedingly rare faculty of being able to view things from an AngloSaxon viewpoint, which made her ... an excellent interpreter of Western thought and temperament. [And she managed this without significantly losing] her Japanese qualities or instincts in any degree. Her character as a Japanese woman was enlarged, enriched, and broadened by the knowledge she had gained of the characteristics of her foreign sisters, both of those with whom she came in personal contact and of those whose acquaintance she made by reading. ${ }^{41}$

\section{Missionising marriage}

The goal of these missionary educators was not to churn out Westernised versions of womanhood, regardless of accusations to the contrary, but to insure a steadfast loyalty to Christ. Naturally, Christian values were at times intertwined with the American morals the missionaries espoused. But it is clear from her

38 Ibid., p. 89.

39 Ibid., p. 88 .

40 Wakamatsu Shizuko, "Yesterday and tomorrow," in In Memory of Mrs. Kashi Iwamoto, ed. Iwamoto Yoshiharu, Tokyo: Ryūkei sho sha, 1981, pp. 162-71, first published by Yokohama seisha bunda, 1896, p. 167. 41 Eugene. S. Booth, "Foreword," in In Memory of Mrs. Kashi Iwamoto, ed. Iwamoto Yoshiharu, Tokyo: Ryūkei sho sha, 1981, pp. i-xxvi, first published by Yokohama seisha bunda, 1896, p. v. 
correspondences that Mary Kidder was sensitive to this inevitability and strove to keep Westernisation and Christianisation separate. She endeavoured to create young women who were firm in their Christian faith and who would carry that faith home to their Japanese families. To meet this goal it was important that these Japanese women were able to maintain strong ties to their families so that their families would be receptive to their good influence. In her reports to the Woman's Board of the Reformed Church in America, Mary cites several cases where her young charges influenced parents and siblings to convert to Christianity.

For Mary, and for many of the missionaries at the time, the greatest proof of a Christian future for Japan was in marriage. Converting heathen women may have been the first step in saving the nation; but marrying her to a Christian man was the second. Mary dreamed of all her Christian students marrying men in the faith. And she despaired when time and again her dreams failed to come true. For example, in her 1878 Report she writes:

Five of my pupils have married during the year. I am sorry to say that three of these who were Christians have married heathen. One Christian has married a Christian and is doing effective work with her husband in the Nagasaki field. The fifth had not been long with us and was still a heathen when she left to be married....

... Kuni Tamura, one of those who married heathens, has been much persecuted by her husband and they are at present separated. We cannot say what the end will be perhaps the hand of the Lord is upon her to deepen her Christian character...

... Ko Okada who only left us two months ago, perhaps has not yet felt the unhappiness which is sure to come with a heathen husband whatever his worldly advantages may be....

... She hopes to be the means of his conversion. We pray that this may be so. ${ }^{42}$

Although Mary was generally favourably disposed to Japanese customs and culture, she adamantly detested the Japanese family structure, particularly the custom of arranged marriage. In her correspondence to the United States she frequently noted the keen disappointment she felt when one after another, the girls she had taught were removed from her school so that they could marry men they did not know and certainly did not love. Many of the girls were barely fifteen, and the men they married were frequently far their senior.

42 Mary Kidder, Yokohama, to Dr J.M. Ferris, New York. This correspondence is titled "Report of Ferris Seminary for 1878," and is signed by Mary E. Miller and Emma C. Whitbeck, n.d., FULA, pp. 100-101. 
Mary was resolved to educate her girls as best she could, to foster in them the strength they would need to resist the "evil" customs of their land and to hold out for appropriate marriage partners. Unfortunately, Christian men in Japan were still few and far between.

You can imagine Mary's joy, therefore, when her prized pupil and surrogate daughter Wakamatsu Shizuko found herself engaged to marry a handsome young Christian man, Serada Tasuku in 1886. Mr Serada, whose younger sister was a Ferris student, was an officer in the Imperial Navy. His work with the Japanese Embassy had taken him to the United States where he had lived for a number of years. He was therefore conversant with American customs and mores, and gifted in English. The foreign instructors at Ferris found him absolutely charming. Mary adored him and was instrumental in arranging that he and Shizuko become engaged to marry. She was understandably dismayed, therefore, when Shizuko broke her engagement one year later. No amount of pleading could persuade her to change her mind. Shizuko divulged no excuses. But as she was to become a writer, we can turn to her later prose fiction and essays for possible answers.

\section{A Japanese New Woman}

Shizuko's 1889 short story Sumire (Violet) seems to offer an explanation. Serialised in Jogaku zasshi (The Woman's Education Journal), the story describes the "friendship" between Miss Sumire Mano and her frustrated suitor, Mr Sawabe. Miss Sumire is an orphan (Figure 11). Educated in a mission-school, she is a Christian, economically independent, and twenty-four-years old. As the story opens, she is being courted by the handsome, courteous, and dignified Mr Sawabe, who has recently returned to Japan with a degree from a university in Berlin. Inexplicably, Sumire has turned down his marriage proposal. He is stunned.

"Do you not enjoy my company? Have you not relied on me as a dear friend? I say this at the risk of being judged overly persistent, but I must state unequivocally that I consider you a friend among friends. Amidst all of Womankind you are the woman whom I most ardently respect. Our friendship began so happily, and it is my fondest desire that we allow it to grow to even greater heights. Yet you will not even consider such. I do not understand why [emphasis in original]."43

43 Wakamatsu Shizuko, "Sumire," Jogaku zasshi 183 (19 October 1889): 215-16. Words italicised in the translation are rendered in English in the original. 


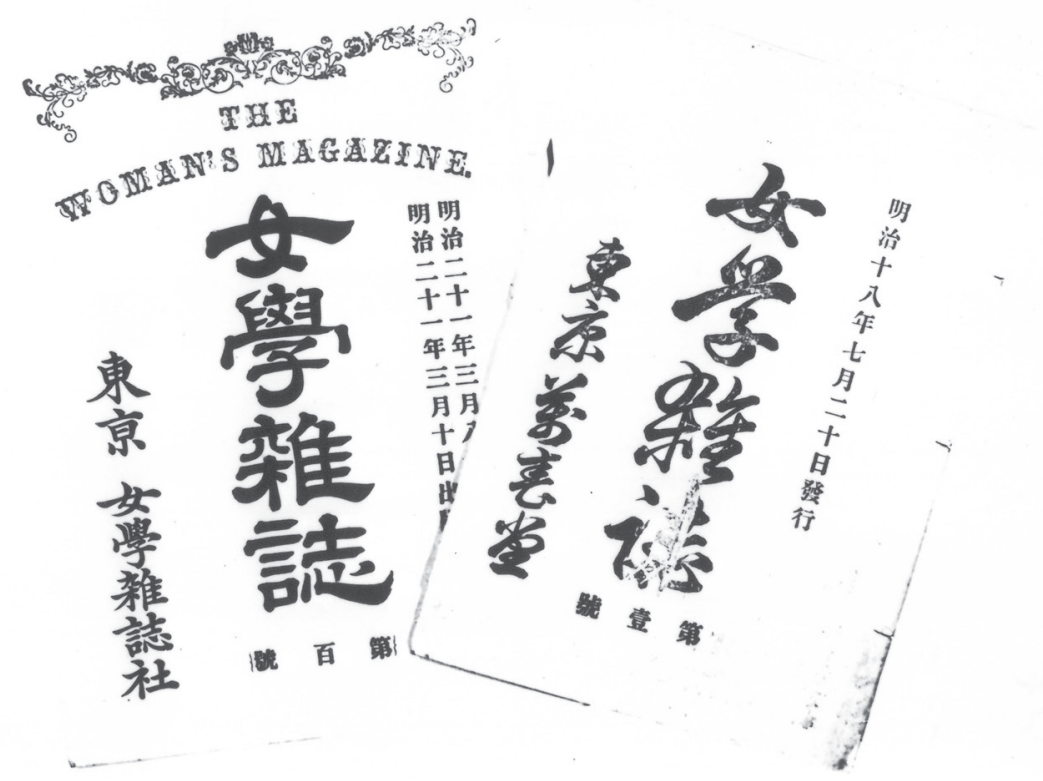

Figure 11. Jogaku zasshi, 1885-1904

Source: The Nihon Kindai Bungakukan (Museum of Modern Japanese Literature).

Mr Sawabe is the ideal Meiji man. Intelligent, sophisticated, sensitive to female concerns, he is in quest of that ever-ephemeral "perfect woman" who will complete him, and who will assist him in creating that equally ephemeral "perfect home." He tells Sumire: "While I was in America, I lived for a time in a Christian home that was remarkable in its perfect beauty. Having received the benefits thereof, I have been progressively distressed by the unsatisfactory home life that I have witnessed here upon my return." ${ }^{44}$

Dissatisfaction with the present condition of Japanese home life was indeed a central concern for Japanese intellectuals, such as Fukuzawa Yukichi(1835-1901), founder of Keio University, and Iwamoto Yoshiharu (1863-1942), the editor of the above-mentioned Women's Education Journal and the chief administrator of Meiji Women's School, founded by Japanese Christians in 1885. Contributions to the short-lived Meiroku zasshi (Meiji-Six Journal) (1874-1875), bear out this attention to Japanese family reform. Meiji intellectuals criticised the traditional family codes for warping Japanese womanhood and for denying Japanese men the joy of a warm and wholesome "home" life. A true "home" (written in katakana 
as hōmu) was warm and sweet and produced by the voluntary union of a man and woman who turned to one another for companionship. "Voluntary" was of course the key to this family unit. Traditional views of marriage venerated family hierarchy and history over individual choice. Women, and men as well, were generally married by patriarchal decree. The individual's interest in the intended union was not often an item of consideration. Japanese men who had had the opportunity to travel in the West were intrigued by the kinds of marriages that they saw there-marriages that they presumed were based on individual selection. Equally novel was the notion that men might engage women in meaningful conversations and exchanges of ideas.

When the author Shizuko learned that others were criticising her decision to break her engagement, she defended her views on marriage in a fairly testy essay entitled "Tama no koshi" (The Jeweled Palanquin), also published in The Women's Education Journal two months later.

I find there is no proverb more harmful to women than the one lauding the orphan maiden who marrying above her station, is "borne aloft in a jeweled palanquin." In our society, a poor woman may marry into the manor, and all will applaud her great fortune. When I hear such I feel my heart is being rent with a sword. ${ }^{45}$

Marriage for Shizuko was not to be a conveyance for female advancement. Nor were women to rush into matrimony at the cost of their own integrity. It seems likely, therefore, that though Shizuko admired and respected her suitor, she did not love him. No matter what her reason, however, a twenty-fouryear-old woman's refusal of marriage must have seemed childish, selfish and irresponsible. Both of the systems that Shizuko had been raised to respectJapanese and Protestant American - viewed marriage as the centre of a woman's life. That Shizuko was willing to face the censure of those closest and dearest to her-indeed that she would break the heart of Mary Kidder Miller — shows the strength of her own convictions.

Similarly, Shizuko creates in her alter ego, Sumire, a pure and principled resistance. Sumire will not marry merely for the sake of convention. Or, in Wada Shigejir's words:

The woman here described is not the radical women's rights agitator, nor is she the childishly sweet maiden tucked protectively away in her room. This is woman of superior intelligence who possesses great selfawareness. In short, she is an idealized woman. Indeed, in her we sense Shizuko herself - or rather a sanctification of her ideal self. I suppose 
there is a cloying touch of narcissism here, but we can also perceive in her portrayal an overwhelming sense of mission as an enlightened individual to advance her cause while clinging to her idealism. ${ }^{46}$

The scenario that Shizuko crafted of a man and woman speaking intelligently and as equals about such ethereal subjects as friendship and platonic love was, as Wada has implied, ahead of its time. The notion that marriage should be premised on love and that the love between a man and woman could circumvent the purely physical and unfold on a spiritual level was still an unusual topic in Japan. But what is most surprising about Shizuko's text is that it does not end in marriage. Almost all the stories at the time inevitably viewed women within the frame of the marriage system. They were either young maidens on the brink of matrimony often torn between suitors - such as Futabatei Shimei's Osei in Ukigumo (Drifting Clouds, 1888), or they were newly married women struggling to adjust to the disappointment and misery of their wedded state - as in the case of Otane in Tsubouchi Shōyō's Saikun (The Wife, 1889). By concluding her tale with the denial of matrimony, Shizuko shifts attention away from marriage as the inevitable conclusion to a woman's life and onto Sumire as an individual.

Sumire's reasons for declining Sawabe's proposal are tethered loosely to an early love for a man who died young. But Shizuko's focus in the story is less on what motivates Sumire's rejection of marriage and more on her choice to do so. Whatever her reasons, Sumire said "No." And it is her ability to do so that Shizuko celebrates. By saying "no," by establishing her own volition, Sumire represents a new type of woman. In Sumire, Shizuko creates a woman who is "feminine," virtuous and pure, yet independent.

Shizuko's reasons for refusing to marry Serada are equally vague. She was not opposed to marriage per se. To the contrary, Shizuko-like her mentorsbelieved that marriage was the centre of a woman's life. But she also believed that marriage was to be a partnership. And she longed for a marriage that would allow her to continue to contribute to society in the way she had been trained. She had grown up under the influence of missionaries and had observed their constant dedication and sacrifice in their determination to make Japan a "better place." Many of the women she was closest to were single, and purposefully so, manifesting the "conviction that a life in service to God and to womanhood was more valuable than fulfilling the Victorian ideals of marriage, motherhood, and domestic bliss." ${ }^{47}$ Shizuko, too, wished to dedicate her life to the mission. In addition to assisting the missionaries with their goals, Shizuko resolved to work

\footnotetext{
46 Wada Shigejirō, "Wakamatsu Shizuko," in Meiji zenki joryū sakuhinron-Higuchi Ichiyō to sono zengo, Tokyo: Ōfūsha, 1989, pp. 276-80, p. 278.

47 Seat, "Providence Has Freed Our Hands," p. 2.
} 
with her pen - to write - for the betterment of her sisters and brothers. In fact, she believed that through writing a woman could help to "cleanse the filthy air of society." 48

\section{Modelling marriage}

What I find interesting in Shizuko's behaviour is the possibility that she was influenced to stick to her principles by the very woman who was most determined to see her marry. Mary had offered herself as a text for Shizuko - as a model for Christian womanhood. And Shizuko had learned well by her. I say this because of Miss Kidder's own marriage and the inspiration it provided her many female students.

After only three years in Japan, Mary married the aforementioned Rothesay Miller (1843-1915), a Presbyterian missionary (see Figure 12). Miller was the product of a wealthy family. His father had been successful in the steel industry, and Miller had enjoyed the luxury of an elite education: Washington University in St. Louis, Princeton, and the Princeton Seminary. Shortly after graduating from the seminary, he was dispatched as a missionary to Japan. And within months after his arrival there in the summer of 1872, he was engaged to Mary Kidder. Some speculate - tantalisingly so - that they had known each other in New York - where Miller's father had an office - and that Miller had followed Mary to Japan. ${ }^{49}$ Their wedding ceremony, which took place on July 10, 1873, was simple but purposely conducted so that it could be viewed by an audience. Miss Kidder invited all of "her girls," and most attended. She wanted them to see a "Christian wedding." What they saw was a bride who was by then an ancient thirty-nine, her husband ten years her junior. The wedding sent shock waves through the missionary community in Japan, waves that carried all the way to the mission offices in the United States.

It seems both mission boards-Mr Miller's Presbyterian and his wife's Reformed Church were alarmed by the marriage. There was the matter of age-both the wife's advanced age and her groom's relative "youth." But there was also the question of the Ferris School and the different mission boards. Most assumed that Mary would resign her post (and salary) to join her husband on the Presbyterian Mission. She even received letters from ladies' church groups welcoming her into the Presbyterian fold. But Mary Miller had no intention

48 As cited in Rebecca L. Copeland, Lost Leaves: Women Writers of Meiji Japan, Honolulu: University of Hawai'i Press, 2000, p. 37.

49 Nakajima Kōji, "Senkyōshi E. Rōsei Mirā," in Ayumi: Ferris Archives Bulletin 38 (1996): 1-32, p. 14. 
of abandoning her fledgling school, then in the process of acquiring building funds. As she states in a letter to J.M. Ferris, informing him of her intention to marry Rothesay:

Do not think that I have or shall lose my interest in my school. I shall not. If you build a schoolhouse for us, I shall stay in school as long as I can. You will perhaps think it is a misfortune that we are not connected with the same board but if you very much desire it I think Mr M would come over to the service of our Board. ${ }^{50}$

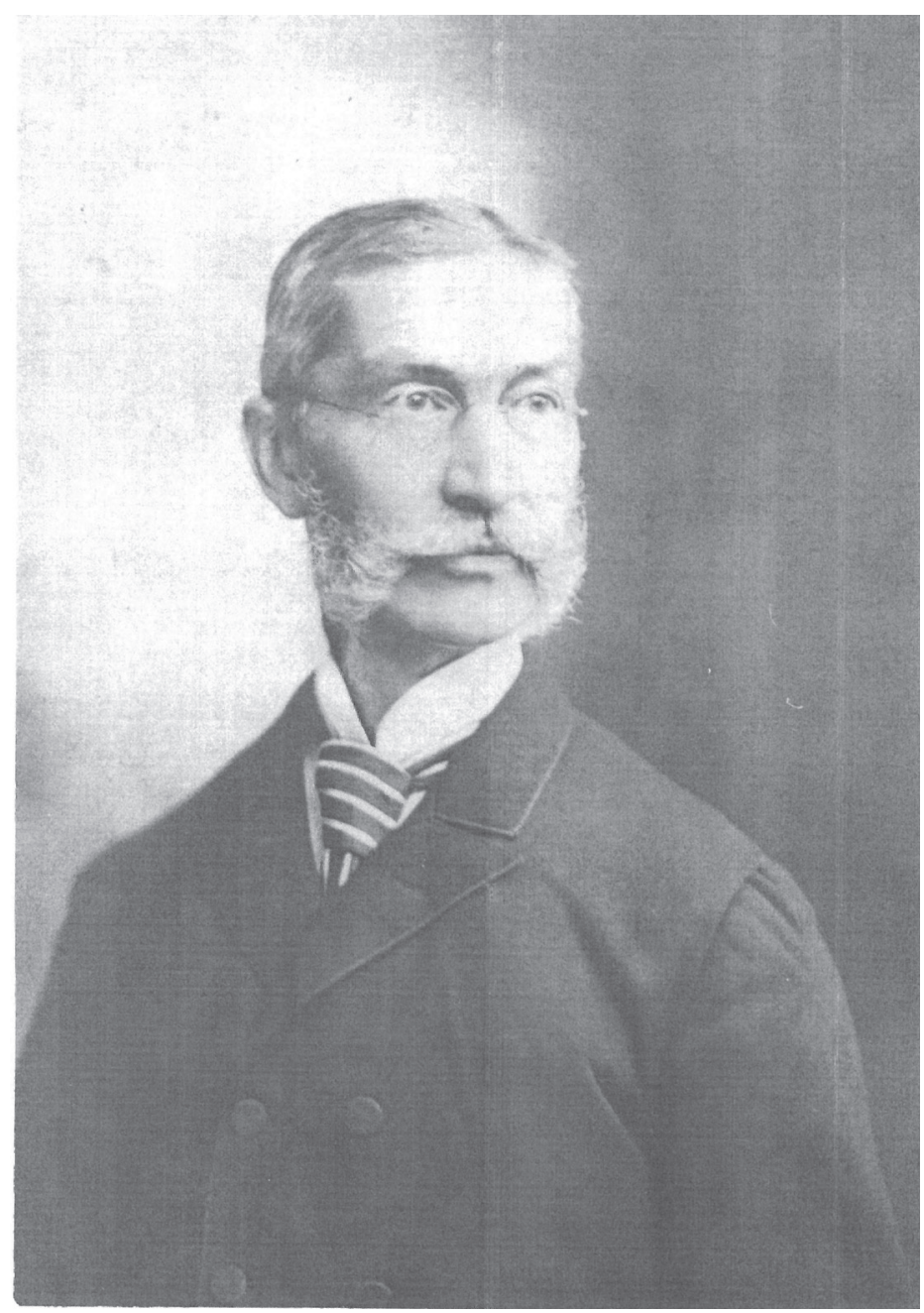

Figure 12. Rothesay Miller (1843-1915)

Source: Ferris University Library Archives.

50 Mary Kidder, Yokohama, to Dr J.M. Ferris, New York, 19 April 1873, p. 42. 
Mary Miller also considered "taking the school with her" to the Presbyteriansshould she be required to join her husband's church — and it seems the Hepburns (particularly Mrs. Hepburn) began to argue that since the school had begun on their compound in 1870 it was Presbyterian all along. This intelligence riled Ferris, as he had just got the Reformed Church Mission Board to raise $\$ 5,000$ for the school dormitory! And it provoked a lengthy letter from Mary in which she tried to set the record straight about "her" school.

Will give you a history of the school and you can judge to whom it belongs... Mrs. Hepburn asked me to teach those girls whom she had been teaching \& I think also some boys, although I am not sure that they had been her pupils before coming to me.... I taught in the Pres. Dispensary because it was not used and it was convenient. Mrs. H. had previously taught in her own house.

During the year I made every effort to get pupils and succeeded in getting six girls in all and then told the boys that I could teach them no longer... I never spoke of it as a school but my class. At the end of the second year, Dr \& Mrs. Hepburn returned from China where the Dr had been for months publishing his dictionary. He told me he wished to use the dispensary and advised me to try to find another place for my school, never in anyway indicated that it was theirs. Nor has anyone else ever thought of such a thing.... Mrs. H. had never assisted me an hour since I began to teach.

I hope this letter will set your mind quite at rest about the school \& no one can take it away from me unless I say I will not teach the girls. ${ }^{51}$

Much of the discomfort over the marriage also revolved around the question of salary. It was unprecedented for a missionary couple to receive separate salaries. Generally appointed as a couple, the husband received a salary plus an allowance for his wife - this regardless of the extent of work that she did for the missions. But Mary continued to receive her salary from the Reformed Church, and Miller from the Presbyterians. As Mary explained to Ferris in the above cited correspondence, "All the missionaries here think we are quite right in each continuing in separate Boards if we prefer it." ${ }^{2}$

But apparently not all the missionaries were in agreement with the Millers' status. In a letter dated September 26, 1874, nearly ten months after the above letter, Mary complains to Ferris,

Nearly every letter from the Secretary of the Pres. Board to the mission here, has some disagreeable saying concerning me.... In the last letter 
the Rev. Sec. says “The Reformed Church Board are about sending out a teacher to Mrs. Miller's school. Soon to be followed by another. The sooner the better for we cannot help feeling that it would be far better for Mr \& Mrs. Miller to be in Yedo." Why I do not know. Mrs. Hepburn has never been cordial since she returned from America and found I was not under the Pres. Board but the Dr is too good a man to be influenced by such a circumstance and is as cordial as ever. ${ }^{53}$

In the end, after much bickering, cruel gossip, and backbiting, Mr Miller resigned from his post as a Presbyterian missionary, relinquished his salary, and joined his wife in her mission - all so that she would not be forced to leave her school. In addition to these sacrifices and his contribution of money and time to the building project for the school, he began working alongside Maryattending to his own studies and sermon preparation in the mornings, and helping at the school in the afternoons. His behaviour dismayed the missionary community and precipitated a letter from Ferris in which he cautioned Mary that "the husband is the head of the household." She responded immediately to assure Ferris that she had no intention of usurping her husband's rightful role as household head - nor had she been advocating that women preach (apparently there had been nasty rumours). ${ }^{54}$

We had quite a laugh over your little speech to us in regard to our mutual relations. I exactly agree with you that the husband is head of the wife not only in theory but in practice, and so we have exactly agreed in all our plans for missionary work. Mr Miller told Dr Hepburn plainly ... that if I come over to their mission I could not take the school, that he would not permit it for he did not think it right. However, although it was pleasant for me to remain in school, we thought it not best and so concluded that as soon as some teachers were sent out I should leave it to go with Mr Miller. This was our only plan till the letter about which I wrote you in Sept. came which caused my husband to resign his connection with the Pres. Mission.

53 Ibid., 26 September 1874, p. 63.

54 The Reformed Church, like many Protestant organisations at the time, did not tolerate women speaking authoritatively to mixed gatherings - let alone preaching from the pulpit. Apparently Ferris had heard rumours that Mary's students were behaving improperly. Mary responded:

Your views in regard to women speaking or praying in mixed company exactly coincide with my own and I am sure that none of my pupils have done anything that you would disapprove of. When we were on a trip north in the Summer we were staying with the relatives of some of our pupils, one of them a girl of fifteen. She helped me in talking to natives mostly men who came where we were staying to ask about our religion. There was nothing like preaching, we all sat down, they asked us questions and we answered them, sometimes talking hours in this way. Sometimes there were but one or two present and at other times twenty to thirty. That is all the "preaching" either myself or my pupils have done (Mary Kidder, Yokohama, to Dr J.M. Ferris, New York, 8 January 1875, p. 73). 
I did not influence my husband to do that, indeed I felt badly about it, at the same time I thought it was right and that it was a providential arrangement for me to be allowed to remain in my school. ${ }^{55}$

Mary even assured the General Secretary that she had Mr Miller read and approve of all her correspondence before she set it to post. Somehow one doubts that a woman who had managed to write her own letters for thirty-some years would suddenly feel moved to seek her husband's approval, but here she is at the end of this particular letter remarking: "You may laugh over my letter but I asked Mr Miller if I might write you what I pleased provided I would be very wise, to which he said, 'yes.' So I have written what I have." 56

The legacy of Christian womanhood that Mary bequeathed to Wakamatsu Shizuko, therefore, was one that "gained its highest glory from its ability to exercise power indirectly through suasion and influence." ${ }^{57}$ She pursued her goals with quiet determination. As Karen Seat notes, "A zealous, selfsacrificing, and even (as some might conclude) masochistic missionary spirit was deeply embedded in American Protestanism, which stood in tension with the domestic ideal of protecting women and the private sphere." ${ }^{18}$ And here lies the irony. Mary, and missionary women like her, had come to Japan eager to uplift heathen women and rescue them from their presumed oppression. ${ }^{59}$ They were eager to convert women who would then "replicate the values of middleclass American Protestants in raising future generations." ${ }^{60}$ But the presence of these women in foreign lands, particularly single women, exposed the foreign subject to examples of New Women, "women defined not by their domestic subordination but by their confidence that they had something of their own to offer their fellows." ${ }^{\prime 61}$

Mary effectively offered Shizuko and her contemporaries a new model for marriage. She had married for love - not for procreation, nor for protection. And she had married a man who supported her goals (in the guise of God's goals) and not one who demanded that she yield to his. With this as her text, therefore, it is not surprising that Shizuko would have felt compelled to resist a marriage that she perhaps intuited would deny her the ability to fulfill her own mission. In her short story, Sumire, she has the suitor trying to win the hand of the protagonist

\footnotetext{
55 Mary Kidder, Yokohama, to Dr. J.M. Ferris, New York, 8 January 1875, p. 71.

56 Ibid., p. 73.

57 Jane H. Hunter, “Women's mission in historical perspective: American identity and Christian internationalism," in Competing Kingdoms: Women, Mission, Nation, and the American Protestant Empire, 1812-1960, ed. Barbara Reeves-Ellington, Kathryn Kish Sklar and Connie A. Shemo, Durham, NC: Duke University Press, 2010, pp. 19-42, p. 25.

58 Seat, "Providence Has Freed Our Hands," p.46.

59 By way of comparison, see Choi's description of similar encounters between American Protestant missionaries and Korean women in Gender and Mission Encounters in Korea.

60 Seat, "Providence Has Freed Our Hands," p. 7.

61 Hunter, "Women's mission in historical perspective," p. 27.
} 
by declaring that none will make such a perfect helpmeet as she: "The only one who can encourage and support me in both my personal and professional worlds is you. Only you can ... propel me to victory on the battlefields of this world." ${ }^{\prime 2}$ Perhaps Shizuko wished for victory on her own battlefields.

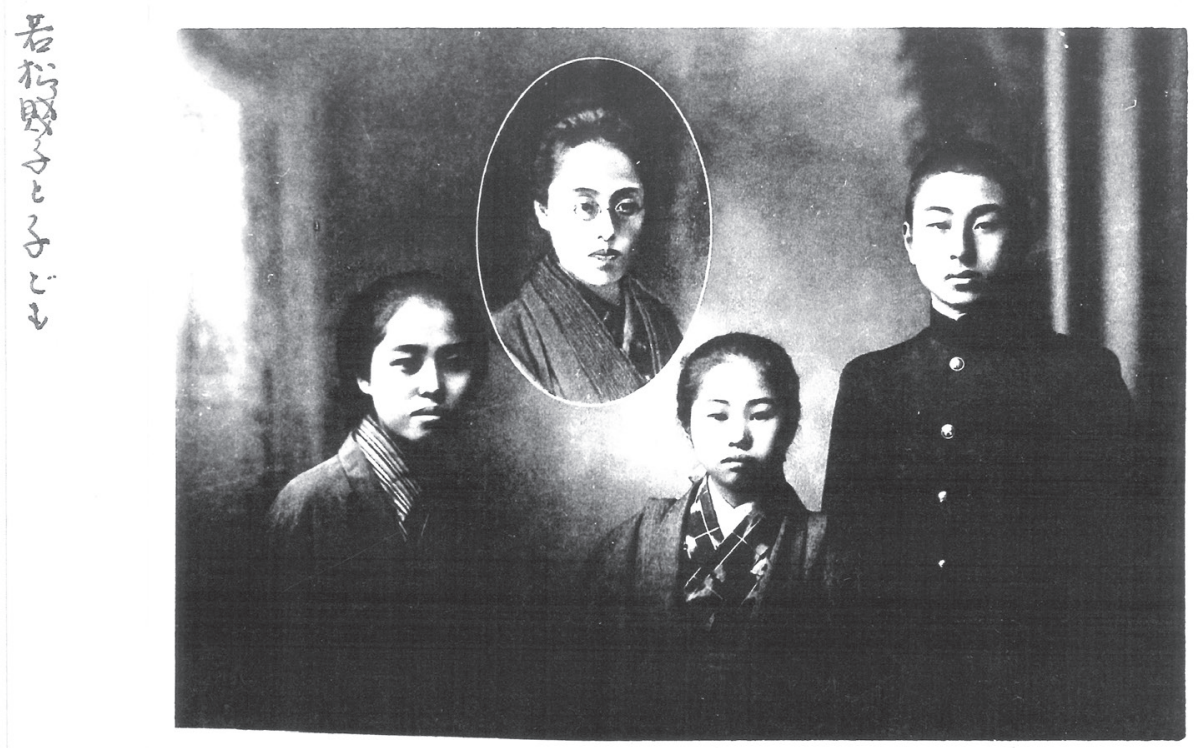

\section{Figure 13. Wakamatsu Shizuko (inset) and her three children}

Source: Ferris University Library Archives.

She was at the time involved in what she saw as important work for Japanese womankind. In a sense, she was carrying on the tradition Mary Kidder Miller had established at Ferris Seminary. But Shizuko was also creating her own path, imbuing her work with her own sense of citizenship and pride as a Japanese woman, a sense that Booth had declared she had never lost, despite her "Anglo-Saxon viewpoint." In addition to teaching Japanese composition, English translation, home economics, and health at Ferris, Shizuko had organised a literature club for women known as the "Jishūkai" or "Society for Timely Reflection." ${ }^{63}$ Profoundly interested in helping others of her sex to enjoy the kind of education she had received, Shizuko was keen on doing what she could to promote improvements in social conditions for women.

62 Wakamatsu Shizuko, "Sumire," Jogaku zasshi 183 (October 19, 1889): 215-16.

63 Shizuko found the source of her society's name in a Confucian saying. Or as Shizuko described it (in English):

The rather antiquated origin of the term 'jish $\bar{u}$, ' may suggest to you one of our principles; our desire to form a habit of not slighting anything because it is old, and to keep fresh whatever has value in the saying of that venerable sage Confucius, to whom our country owes so much. 
In so doing she sought to make Japanese literature more suitable for women. ${ }^{64}$ In this enterprise she joined a small group of like-minded Meiji intellectuals, among them the editor and educator Iwamato Yoshiharu, a Christian, and a man for whom Shizuko felt the love she had not felt for Serada. ${ }^{65}$ Shortly after Shizuko broke her engagement to Serada she married Iwamoto, much to the delight of her missionary family. Theirs was an excellent match. With Iwamoto as her partner, Shizuko was able to acquit her role as wife and mother (she had three children), ${ }^{6}{ }^{6}$ while also distinguishing herself in the fields of journalism, education and translation (see Figure 13). As Booth, Mary Miller's successor at Ferris Seminary, observed of Shizuko:

A new woman undoubtedly she was, not in the sense, however, which has come to be attached to that term on account of the appearance of a few monstrosities in modern civilization, but a new woman in the highest and best sense. A regenerated woman directed by the forces of a new life. ${ }^{67}$

Both Mary Kidder Miller and her beloved pupil Wakamatsu Shizuko left Japanese women with important legacies (see Figure 14). The school that Mary fought tenaciously to found still stands on the Bluffs of Yokohama, having achieved university status in 1965. Wakamatsu Shizuko, the school's first graduate, went on to earn renown as not only a translator but an early proponent of children's literature in Japan. Clearly inspired by her mentor, Mary Kidder Miller, to whose gazette for children she had contributed, Shizuko was one of the first in Japan to celebrate childhood as a special status. And, like her mentor, Shizuko was able to conceal her own need for agency and independence, behind the cloak of domesticity and mission. Unlike other Japanese women of her generationsuch as Fukuda Hideko or Yajima Kajiko - she did not threaten the patriarchal system - at least not directly. Rather Shizuko knew how to work within the system to accomplish her own aims. In so doing, she presented herself as the exemplary New Woman, and proved that she had inherited Mary Kidder Miller's unintended legacy.

The Chinese teacher in the well-known passage from which the two words are taken comments on the pleasure of acquiring knowledge, and then reviewing or dwelling upon it from time to time. See Shizuko's English essay, “Bungakukai jo," Jogaku zasshi 242 (1890): p. 11.

64 M.E. Miller had called Japanese literature "filthy." It was her disregard of the literary texts available to women that had encouraged her to issue her own gazette for women and children, the Otozure (Good Tidings) series, with which Shizuko had worked. From a digest of Mary Kidder's letters home, Morioka, 15 July 1890.

65 See Rebecca Copeland, "Sex and the lady translator in Meiji Japan or translation as a transsexual act," Proceedings of the Midwest Association for Japanese Literary Studies 5 (1999): 88-95.

66 Her eldest son's daughter, Iwamoto Mari (1926-1979) was a world-renowned violinist.

67 Booth, "Foreword," p. xi. 


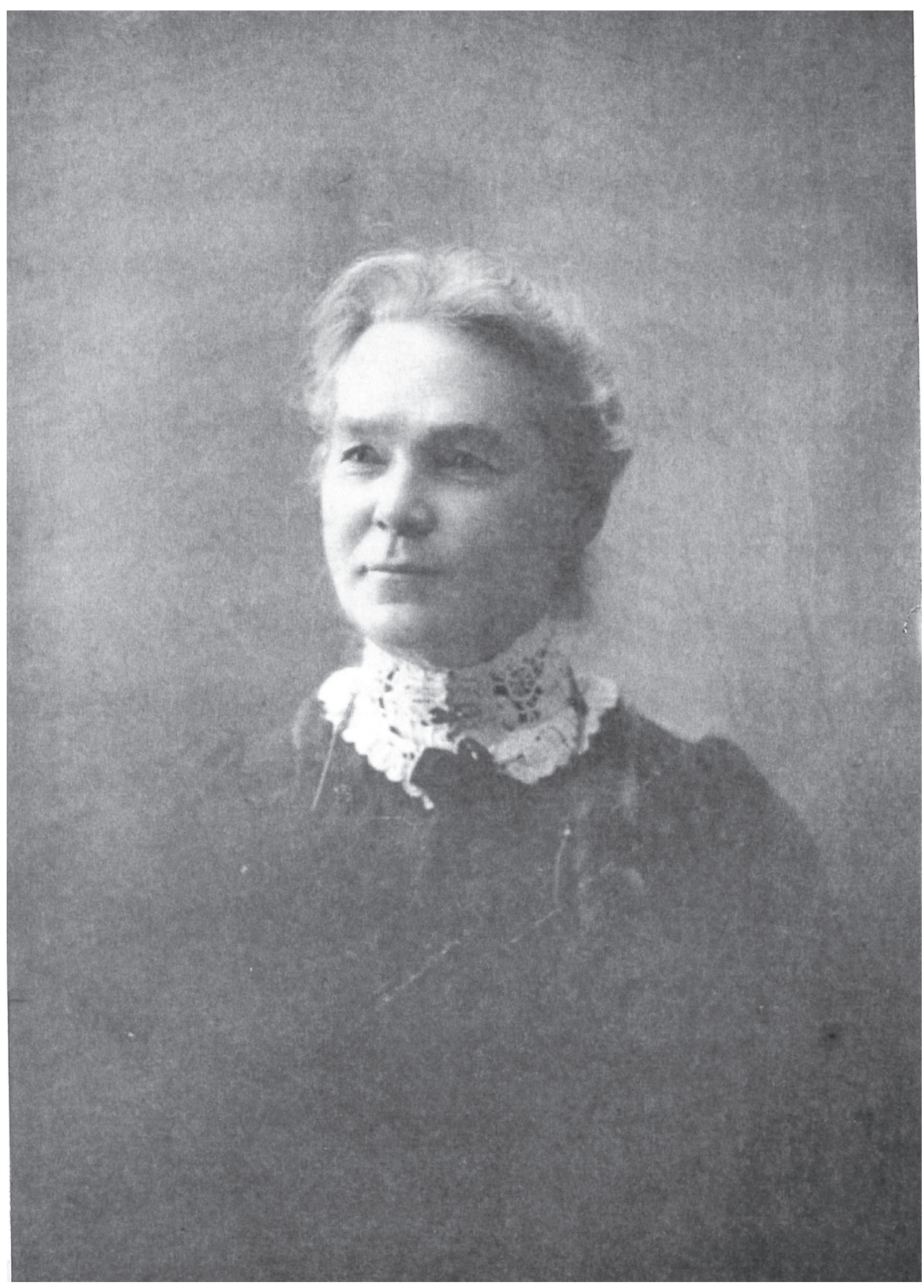

Figure 14. Mrs. Mary Kidder Miller

Source: Ferris University Library Archives. 


\section{Acknowledgements}

I wish to thank Profs Hyaeweol Choi and Margaret Jolly for their tireless work on this volume and their good cheer along the way. Dr Carolyn Brewer has been most patient and careful with edits and explanations. Research for this chapter was conducted at the Ferris University Library Archives in Yokohama, Japan, where I was very grateful to Ms. Kazuko Nakayama for her help and guidance. I also profited immensely from the holdings at the International Christian University. Whereas my own field of research is literature, I was influenced to undertake this topic due to more personal concerns. My parents were missionaries to Japan involved in education and themselves developed lasting and dear relationships with many of the young women they encountered there. I dedicate this chapter to their memory. 
This text taken from Divine Domesticities: Christian paradoxes in Asia and the Pacific, edited by Hyaeweol Choi and Margaret Jolly, published 2014 by ANU Press, The Australian National University, Canberra, Australia. 